<smiles>C=CC=CC</smiles>

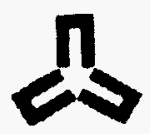

MIM-MU-91-64-0006
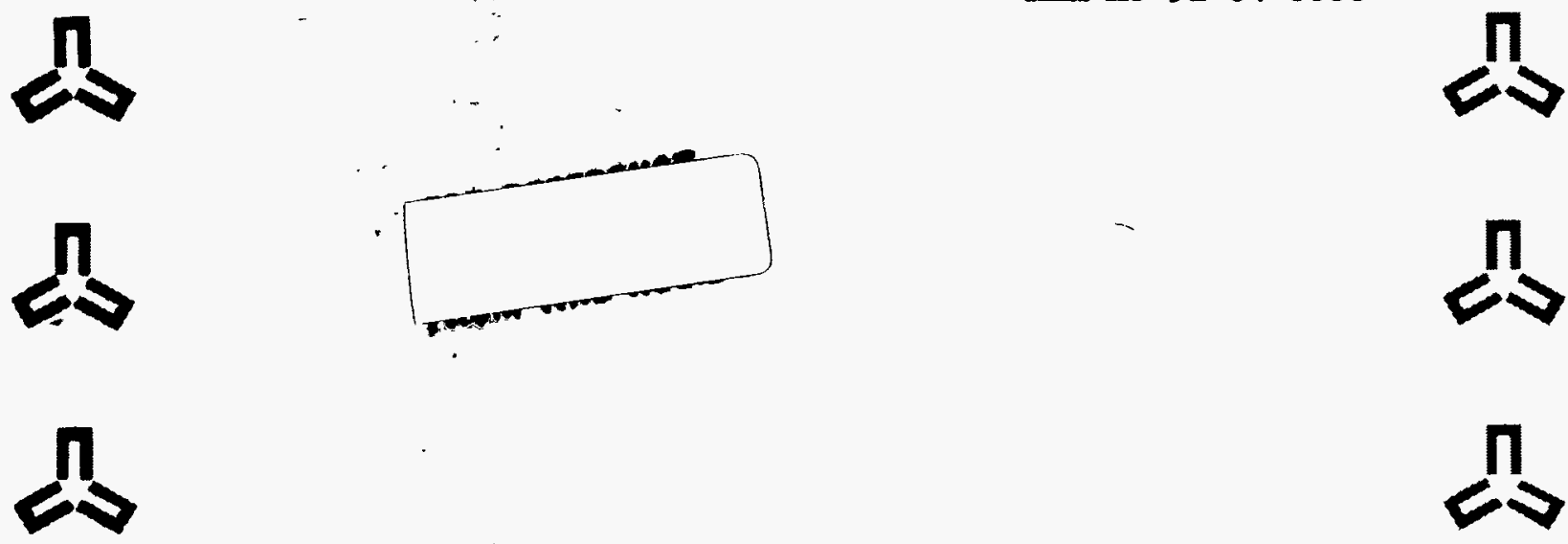

PROPOSED GTA WRLDING SPECIFICATION

AND ACCEPTANCE CRITERIA

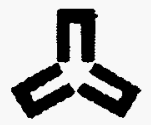

FOR THE MC4163

APRIL 12, 1991

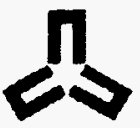

JOSEPH J. KHIATKOWSKI

RE

$$
\begin{aligned}
& \text { OSTL OTI } \\
& \text { OSTI }
\end{aligned}
$$

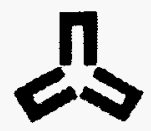

$\infty$<smiles>C=CC=C</smiles>

$\triangle$ DEG 2 G MOUND APPLIED TECHNOLOGIES

P.O. BOX $300^{\circ}$

MIAMISBURG, OHIO 45343-3000

$513-865-4020$

operated for the UNITED STATES DEPARTMENT OF ENERGY

Contract No. DE-AC04-88-DP43495 


\section{PROPOSED GTA WELDING SPECIFICATION \\ AND ACCEPTANCE CRITERIA \\ FOR THE MC4163}

APRIL 12, 1991

JOSEPH J. KWIATKOWSKI

\section{DISCLAIMER}

This report was prepared as an account of work sponsored by an agency of the United States Government. Neither the United States Government nor any agency thereof, nor any of their employees, makes any warranty, express or implied, or assumes any legal liability or responsibility for the accuracy, completeness, or usefulness of any information, apparatus, product, or process disclosed, or represents that its use would not infringe privately owned rights. Reference herein to any specific commercial product, process, or service by trade name, trademark, manufacturer, or otherwise does not necessarily constitute or imply its endorsement, recommendation, or favoring by the United States Government or any agency thereof. The views and opinions of authors expressed herein do not necessarily state or reflect those of the United States Government or any agency thereof. 


\section{DISCLAIMER}

Portions of this document may be illegible in electronic image products. Images are produced from the best available original document. 
Proposed GTA Welding Specification and Weld Acceptance Criteria for the MC4163

\section{General}

1.1 Scope - This specification documents the gas tungsten arc (GIA) welding process and production weld acceptance criteria requirements for the MC4163. This document is written specifically to apply to the welds on the MC4163 and is not to be used as a general gas tungsten arc welding specification.

1.2 All sections of this specification must be complied with unless specifically exempted in writing.

1.3 There are a total of five welds with three different joint designs required to fabricate the MC4163. In the order of fabrication they are (1) initiator closure disc, (2) nozzle to case girth welds, two and, (3) nozzle closure disc welds, two. This specification will only address the nozzle to case girth welds and the nozzle closure disc welds.

\section{Documents and Equipment}

\subsection{Required Documents}

AY411778

2.2 Required Equipment

a. Gas tungsten arc welding system with an automatic sequence controller.

b. Power supply capable of delivering pulsed or continuous DCEN welding current. The power supply shall also be equipped with arc starting equipment which will initiate the arc without the electrode touching the workpiece.

c. Rotary fixture capable of turning the assembly at a constant velocity.

3. Procedure

3.1 Process - The gas tungsten arc welding process shall be used on the weldments.

3.2 Filler Material - Filler wire (cold wire) shall be used on the nozzle to case girth welds. The nozzle closure disc welds have been designed so that filler material is not required and shall not be used.

3.3 Shielding Gas - Welding grade argon gas shall be used through the torch to protect the weld from the atmosphere. Argon shall also be used as a backing gas on the nozzle to case girth welds. 
3.4 Penetration - The effective weld throat shall be as indicated on the drawings. Welding techniques shall be used that will result in minimum heat input to the assembly. During the weld development phase of the program, thermocouple data which indicates the temperature rise profile of critical locations in the assembly shall be obtained on representative weld samples for all weld joint designs.

3.5 Component Cleanliness - Components to be welded shall be free of oil, grease, visible oxide, marking materials or other contaminants that may be detrimental to weld quality.

3.6 Calibration - As a minimm, the weld current and rotation speed shall be calibrated on all systems. On the pulsed systems, the pulse length and frequency shall also be calibrated.

3.7 Machine Journal - A journal shall be maintained for the GTA welding system to document the following activities:

a. All machine maintenance.

b. Weld schedule certification record.

c. Iist of qualified operators for WR production and dates of qualification.

3.8 Weld Schedule - The following welding parameters and information items are the minimm that shall be documented for the welding schedule.

a. Welding schedule identification number

b. Subassembly drawing number

c. Material combination at the weld joint

d. Identification of the welding equipment

e. Identification of fixture

f. Up-slope setting

g. Weld current setting

h. Pulse Frequency setting (on pulsed current system)

i. Background current setting (pulsed current system)

j. Low pulse width setting (pulsed current system)

k. Down-slope setting

1. Initial current setting

m. Arc start amplitude

n. Arc start width

o. Pre-purge time

p. Weld duration time

q. Post purge time

r. Gas flow rate

s. Electrode type and size

t. Electrode to work gap

u. Electrode end configuration

v. Relative position of the electrode to the weld joint

w. Filler wire type, diameter, and feed rate 


\subsection{Certifications}

3.9.1 Welding Schedule - All GIA welding schedules used in WR production must be certified. Two samples of each weld joint design shall be made and subjected to the requirements of Section 4. All the machine control settings must be changed and reset between the samples.

The recertification of the schedule must be done when a different heat of any of the materials which make up the particular weld joint is used.

3.9.2 Operator - Since this GIA welding operation is an automatic welding process requiring only minimal operator skill, a formalized operator certification utilizing sample welds will not be required. The program engineer shall instruct each welding operator on the procedures for making the weld as outlined on the operation sheet. After the operator has satisfactorily demonstrated his/her skill to properly operate the welding system, the operator's name and date shall be recorded in the machine journal. If there is evidence of unsatisfactory performance on the part of a welding operator, the engineer can disqualify or retrain that operator. The incident shall be recorded in the machine journal.

\section{Weld Acceptance Criteria}

4.1 Visual Examination - The program welding engineer shall instruct the Quality control personnel on visual examination techniques and evaluation criteria for the weldments. The program welding engineer shall supply quality comparison sample welds that can be used as needed for a reference. All welds shall be inspected at 10X-50X magnification using fluorescent lighting. The following criteria shall be used to accept each weld:

4.1.1 Cracks - There shall be no cracks in the weld or adjacent base metal.

4.1.2 Pores - There shall be no surface pores larger than $0.25 \mathrm{~mm}$ in diameter.

4.1.3 Size and Shape - The size and shape shall be comparable to the quality sample. Direct comparison to the quality comparison samples is only needed for training. 
4.2 Destructive Tests - At the start of each production lot, a representative weld sample of each weld joint design shall be made and given to quality control for metallographic examination. The criteria in section 4, except for proof testing (4.4), shall be used to evaluate these process control samples. Each weld sample shall be cut into 4 transverse sections and metallographically prepared.

.2 .1 cracks - There shall be no cracks in the weld and heat affected zone.

4.2.2 Pores - There shall be no pores in the weld cross-sections with a diameter greater than $35 \%$ of the weld throat thickness. There can be any number of small pores as long as the total area of all the pores doesn't exceed the area of one pore of the maximum allowable size.

4.2.3 Size and Configuration - The size and shape of the welds shall be similar to those sectioned previously.

4.2.4 Depth of Penetration - The effective weld throat shall meet the requirements on the drawing.

4.3 Helium Leak Test - The completed welds shall meet the leak test requirements on the drawing.

4.4 Proof Testing - The nozzle to case girth welds shall meet the proof test requirements on the drawing.

5. Weld Rework

5.1 No weld joints shall be rewelded without a review by the program welding, quality control, and product engineers. If it is the opinion of any member of the review team that a defect cannot be repaired without degradation to the weld joint strength and integrity, the unit shall be rejected. When repairs can be made to correct the defect, the program welding engineer shall specify the welding repair procedure to be used. After repair, the weld shall again be submitted to all of the weld inspections required for the original weld. Any weld repairs shall be documented on the assembly traveler. 
DISTRIBUTTON

J. R. McDougal

W. H. Jones

T. G. Nelson

Document control (3)

SNLA

I. M. Ioyola

M. R. Kopczewski 